\title{
Role of calcium/calmodulin-dependent protein kinase II in gonadotrophin-induced ovulation in in vitro perfused rabbit ovaries
}

\author{
K. Kugu, A. M. Dharmarajan, S. Preutthipan and E. E. Wallach* \\ Department of Gynecology and Obstetrics, The Johns Hopkins University School of Medicine, Baltimore, \\ MD 21205, USA
}

\begin{abstract}
The objectives of these experiments were to determine (i) the role of calcium/calmodulindependent protein kinase II-mediated signal transduction in hCG-induced ovulation and (ii) whether there is an association between arachidonic acid metabolites, nitric oxide and calcium/calmodulin-dependent protein kinase II in the overall scheme of ovulation induction. Ovarian arteries were cannulated in situ, and the ovaries were excised and perfused in vitro. Ovulatory efficiency (nnumber of ovulated follicles/number of mature follicles $>1.5 \mathrm{~mm}] \times 100$ ) was calculated for each experiment. Calcium/calmodulin-dependent protein kinase II substrate induced ovulation in the absence of gonadotrophin (calcium/ calmodulin-dependent protein kinase II substrate: $66.3 \%$; control: $0 \%$ ). In the next experiment, perfusion medium of the experimental ovary was supplemented with $\mathrm{KN} 62$, a potent inhibitor of calcium/calmodulin-dependent protein kinase II, while the contralateral ovary served as control. Ovulations were induced in both ovaries with hCG (50 iu $\left.(150 \mathrm{ml})^{-1}\right)$ and perfusion was continued for $8 \mathrm{~h}$. In the third experiment, ovaries were

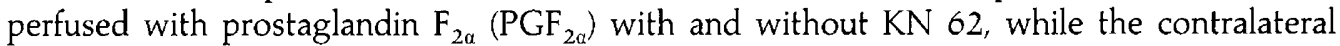
ovary was perfused with medium alone. KN 62 reduced the ovulatory efficiency of hCG-treated ovaries in vitro during perfusion (hCG $+10^{-7} \mathrm{~mol} \mathrm{KN} 62 \mathrm{l}^{-1}: 32.9 \%$; hCG: $80.9 \%$ ). Furthermore, it significantly reduced the ovulatory efficiency of $\mathrm{PGF}_{2 \alpha}$-treated ovaries $\left(\mathrm{PGF}_{2 \alpha}+\mathrm{KN} 62=21.5 \% ; \mathrm{PGF}_{2 \alpha}=59.9 \%\right)$. In the final experiment, $N$-nitro-Larginine methyl ester, an inhibitor of nitric oxide synthase, reduced ovulation calcium/ calmodulin-dependent protein kinase II substrate, indicating an interaction between ovarian nitric oxide synthesis and calcium/calmodulin-dependent protein kinase II. These findings suggest that the calcium/calmodulin-dependent protein kinase II signal transduction system plays a significant role in hCG-induced ovulation. Furthermore, the data demonstrate an interaction between the arachidonic acid metabolites, nitric oxide and calcium/calmodulindependent protein kinase II pathway.
\end{abstract}

\section{Introduction}

Many tissues, including ovarian tissue, possess at least two major classes of secondary messengers: the cAMP-dependent protein kinase system and the protein kinase $C$ system. The cAMP-dependent protein kinase pathway is widely believed to be the regulator of steroidogenesis in follicular cells (LeMaire and Marsh, 1975; Davis et al., 1986; Adashi et al., 1990) and cAMP has also been implicated in oocyte maturation (Strickland and Beers, 1976; Holmes et al., 1986; Brännström et al., 1987; Hosoi et al., 1989). Workers in our laboratory have found that high concentrations of cAMP inhibited hCGinduced ovulation in a dose-dependent fashion, possibly by decreasing prostaglandin (PG) production (Yoshimura et al., 1994). Less is known about the role of protein kinase $\mathrm{C}$-mediated signal transduction in the activation of tissue

*Correspondence and reprint requests.

Received 17 October 1994. plasminogen activator and follicle rupture during ovulation. The protein kinase $\mathrm{C}$ pathway may be important during the periovulatory interval, both alone and in combination with the cAMP pathway (Kawai and Clark, 1985; Leung and Wang, 1989). It is known that phorbol-12,13-dibutyrate, a phorbol ester known to stimulate protein kinase $C$, leads to ovulation in a dose-dependent manner in the in vitro perfused rabbit ovary in the absence of gonadotrophins and that the calciumdependent protein kinase $C$ pathway is involved in gonadotrophin-dependent protein kinase IImediated follicular rupture (Kaufman et al., 1992).

Protein kinase $\mathrm{C}$-mediated signal transduction requires the coupling of cytoplasmic membrane receptors to $G$ proteins that activate phospholipase $\mathrm{C}$ and, in turn, stimulate the hydrolysis of phosphatidylinositol-4,5-biphosphate into 1,2-diacylglycerol and inositol-1,4,5-triphosphate. Calcium and 1,2-diacylglycerol in combination activate protein kinase $\mathrm{C}$. Inositol-triphosphate can also produce an increase in intracellular calcium by 
liberating stores from endoplasmic reticulum. The increase in intracellular calcium and its subsequent binding to calmodulin is a major mechanism of signal transduction in response to hormonal stimulation or membrane depolarization (Rasmussen and Rasmussen, 1990). Calcium/calmodulin stimulates a wide variety of enzymes, including protein kinases such as the multifunctional calcium/calmodulin-dependent protein kinase II (Colbran and Soderling, 1990; Hanson and Schulman, 1992).

Using an in vitro perfusion model, we investigated specific substances that affect ovulation including eicosanoids (Wallach and Dharmarajan, 1992), proteolytic enzymes and inhibitors (Yoshimura et al., 1987), bradykinin (Yoshimura et al., 1988), oxygen free radical scavengers (Miyazaki et al., 1991a), nitric oxide inhibitors (Hesla et al., 1993), angiotensin II (Kuo et al., 1991), epidermal growth factor (Endo et al., 1992), and interleukin-1 $\beta$ (Takehara et al., 1994). The above agents may also increase intracellular calcium which, in turn, stimulates calcium/calmodulin-dependent protein kinase II and nitric oxide synthase. These observations suggest a role for calcium/ calmodulin-dependent protein kinase II signal transduction in mediating gonadotrophin-induced follicular rupture.

The objectives of the study were to investigate: (i) the effect of calcium/calmodulin-dependent protein kinase II substrate, a stimulator of calcium/calmodulin-dependent protein kinase II, on ovulation and progesterone and prostaglandin production in the absence of gonadotrophins; (ii) the effect of specific calcium/calmodulin-dependent protein kinase II inhibitors on gonadotrophin-induced ovulation and progesterone and prostaglandin production; (iii) the effect of calcium/calmodulindependent protein kinase II inhibitor on $\mathrm{PGF}_{2 \alpha}$-induced ovulation; and (iv) the effect of $N$-nitro-L-arginine methyl ester, an inhibitor of nitric oxide synthase which, in the presence of calcium/calmodulin-dependent protein kinase II, converts L-arginine to citrulline, a reaction of nitric oxide synthesis, on ovulation. The in vitro perfused rabbit ovary model was therefore used to determine the effects of these agents on ovarian function in a carefully controlled and monitored environment.

\section{Materials and Methods}

\section{Animals}

New Zealand White mature female rabbits, $3.0-4.5 \mathrm{~kg}$, were used. All rabbits were caged individually for at least 3 weeks before use. Animals were given water and an unrestricted diet of rabbit chow. Rabbits were anaesthetized i.v. with $32 \mathrm{mg}$ sodium pentobarbital $\mathrm{kg}^{-1}$ body mass (Anpro Pharmaceutical, Arcadia, CA), treated with 120 iu heparin sulfate $\mathrm{kg}^{-1}$ body mass (Invenex Laboratories, Chagrin Falls, $\mathrm{OH}$ ) for anticoagulation, and then subjected to laparotomy. Ovaries were excluded from the study if they were immature or if two or more of the follicles were haemorrhagic at the time of laparotomy. Experimental ovaries were also excluded if the paired contralateral control unstimulated ovary ovulated, presumably as a result of an endogenous LH surge before ovariectomy. All studies were performed in accordance with the National Institutes of Health Guide for the Care and Use of Laboratory Animals.

\section{In vitro perfusion}

The cannulation procedure and perfusion apparatus were described by Lambertsen, Jr et al. (1976), Kobayashi et al. (1981), and Dharmarajan et al. (1988). Each ovarian artery was isolated and cannulated in situ after ligation of the major anastomotic connections. The ovary with its cannulated vascular pedicle and supportive connective tissue was removed. The number of mature follicles ( $>1.5 \mathrm{~mm}$ in diameter) observed on the surface of each ovary was recorded, and the ovary was immediately placed in the perfusion chamber. The perfusion system consists of a chamber containing the ovary, an oxygenator, a reservoir, and a pulsatile roller pump that maintains perfusate flow at $1.5 \mathrm{ml} \mathrm{min}{ }^{-1}$, the approximate blood flow to the rabbit ovary (Ahrén et al., 1971). The oxygenator was gassed with $95 \% \mathrm{O}_{2}: 5 \% \mathrm{CO}_{2}$. Ovaries were perfused for $10.5 \mathrm{~h}$ at $37^{\circ} \mathrm{C}$ in $150 \mathrm{ml}$ medium 199 (Gibco, Grand Island, NY) supplemented with 200 iu heparin sulfate $l^{-1}, 20$ iu insulin $\mathrm{l}^{-1}$ (Novo Nordisk Pharmaceuticals Inc., Princeton, NJ), $50 \mathrm{mg}$ streptomycin sulfate $1^{-1}$ (Sigma Chemical Co., St Louis, MO) and $75 \mathrm{mg}$ penicillin $\mathrm{G}^{-1}$ (Sigma Chemical Co.). Perfusate samples were collected from the arterial cannula at time zero and at $1,2,4,6$, and $8 \mathrm{~h}$ after the administration of either hCG (Organon Inc., West Orange, NJ) or calcium/calmodulindependent protein kinase II substrate (Research Biochemicals International, Natick, MA) and replaced by an equal volume of fresh medium. Samples were stored at $-20^{\circ} \mathrm{C}$ for later determination of progesterone and prostaglandin concentrations. The ovary was monitored for fresh ovulation points every $15 \mathrm{~min}$. A follicle was considered to be ruptured when the cumulus containing an ovum was observed protruding from the ovarian surface. Ovulatory efficiency was calculated for each ovary using the following formula: [number of ovulated follicles/number of mature follicles] $\times 100$ (Lambertsen, Jr et al., 1976; Kobayashi et al., 1981).

\section{Experimental design}

Effect of calcium/calmodulin-dependent protein kinase II substrate on ovulation and progesterone and $P G F_{2 a}$ production and influence of calcium/calmodulin-dependent protein kinase II inhibitor on calcium/ calmodulin-dependent protein kinase II substrate-induced ovulation. These experiments were designed to investigate the effect of calcium/calmodulin-dependent protein kinase II stimulation on ovulation and progesterone and $\mathrm{PGF}_{2 \alpha}$ production, in the absence of hCG. Ten rabbits were used for these experiments. One milligram of calcium/calmodulin-dependent protein kinase II substrate was dissolved in $1.5 \mathrm{ml}$ distilled water as the stock solution, yielding a concentration of $4 \times 10^{-4} \mathrm{~mol} \mathrm{I}^{-1}$. Ovaries were placed in the perfusion chambers at $-0.5 \mathrm{~h}$, and a bolus injection of $0.125 \mathrm{ml}$ of $4 \times 10^{-4} \mathrm{~mol}$ calcium/ calmodulin-dependent protein kinase II substrate $\mathrm{l}^{-1}$ or vehicle alone was administered via an arterial cannula at $\mathrm{Oh}$. Six ovaries were treated with calcium/calmodulin-dependent protein kinase II substrate and observations were compared with those of contralateral control ovaries. Another four rabbits were used for experiments investigating the influence of the calcium/calmodulin-dependent protein kinase II inhibitor, $\mathrm{KN}$ 62 (Calbiochem, La Jolla, CA). One milligram of KN 62 was Downloaded from Bioscientifica.com at 04/26/2023 05:40:33AM 
dissolved in $27.6 \mathrm{ml}$ of $10 \%(\mathrm{v} / \mathrm{v})$ dimethyl sulfoxide as the stock solution. Either KN 62 or vehicle alone was dissolved in $150 \mathrm{ml}$ of perfusion medium at a concentration of $10^{-6} \mathrm{~mol}$ $\mathrm{KN} 62 \mathrm{I}^{-1}$. Ovaries were placed in the perfusion chambers at $-0.5 \mathrm{~h}$, and bolus injections of $0.125 \mathrm{ml}$ of $4 \times 10^{-4} \mathrm{~mol}$ calcium/calmodulin-dependent protein kinase II substrate $1^{-1}$ were administered via arterial cannula at $\mathrm{O}$ h. Four ovaries were perfused with the medium containing $\mathrm{KN} 62$ and observations were compared with those of contralateral ovaries. Samples were collected for determination of progesterone and $\mathrm{PGF}_{2 a}$ concentrations, and ovulatory efficiencies were calculated as described above.

Effects of calcium/calmodulin-dependent protein kinase II inhibitors on hCG-induced ovulation and progesterone and $P G F_{2 a}$ production. These experiments were designed to investigate the effect of calcium/calmodulin-dependent protein kinase II inhibition on hCG-induced ovulation and progesterone and $\mathrm{PGF}_{2 \alpha}$ production. Sixteen rabbits were used for these experiments. The KN 62 was prepared as described above. One milligram of calcium/calmodulin-dependent protein kinase II inhibitor 281-302 (Research Biochemicals International) was dissolved in $1.5 \mathrm{ml}$ of distilled water as the stock solution. Inhibitor or vehicle alone was dissolved in $150 \mathrm{ml}$ of perfusion medium at a concentration of $10^{-9}, 10^{-8}, 10^{-7}$ or $10^{-6} \mathrm{~mol}$ $\mathrm{KN} 62 \mathrm{I}^{-1}$, or $10^{-6} \mathrm{~mol}$ inhibitor $281-302 \mathrm{l}^{-1}$ before the onset of the experiment. Ovaries were placed in the perfusion chambers at $-0.5 \mathrm{~h}$, and $50 \mathrm{iu}$ hCG were administered via the arterial cannula at $\mathrm{O}$ h. Samples were collected for determination of progesterone and $\mathrm{PGF}_{2 \alpha}$ concentrations. Ovulatory efficiencies were calculated as described above.

Effect of calcium/calmodulin-dependent protein kinase II inhibitor (KN 62) on $P G F_{2 u}$-induced ovulation. This experiment was designed to investigate the effect of calcium/calmodulindependent protein kinase II inhibition on $\mathrm{PGF}_{2 a}$-induced ovulation. Six rabbits were used. KN 62 was prepared as described above. Either KN 62 or vehicle alone was dissolved in $150 \mathrm{ml}$ of perfusion medium supplemented with $100 \mathrm{ng} \mathrm{PGF}_{2 \alpha} \mathrm{ml}^{-1}$ (Sigma Chemical Co.) to yield a concentration of $10^{-6} \mathrm{~mol}$ $\mathrm{KN} 62 \mathrm{l}^{-1}$ before the onset of the experiment. Ovulatory efficiencies were calculated as described above.

Influence of nitric oxide synthase inhibitor on ovulation induced by either calcium/calmodulin-dependent protein kinase II substrate or $h C G$. This experiment was designed to investigate the interactions between synthesis of nitric oxide and ovulation induced by calcium/calmodulin-dependent protein kinase II substrate and hCG. $N$-nitro-L-arginine methyl ester (L-NAME; Sigma Chemical Co.) was used as a nitric oxide synthase inhibitor. Ten rabbits were used for this experiment. L-NAME was dissolved into medium directly to yield a concentration of $10^{-5} \mathrm{~mol} \mathrm{l}^{-1}$ before the onset of the experiment. Ovaries were placed in the perfusion chambers with medium containing L-NAME and contralateral ovaries were placed in the perfusion chambers with medium alone at $-0.5 \mathrm{~h}$. Bolus injections of $0.125 \mathrm{ml} 4 \times 10^{-4} \mathrm{~mol}$ calcium/calmodulin-dependent protein kinase II substrate $\mathrm{l}^{-1}$ were administered via arterial cannula at $\mathrm{oh}$. In the second series of experiments, medium of one ovary contained L-NAME while the contralateral ovary served as control. Both ovaries were stimulated at $0 \mathrm{~h}$ with 50 iu of hCG to induce ovulation. Ovulatory efficiencies were calculated as described above.

\section{Progesterone and $P G F_{2 a}$ radioimmunoassays}

Progesterone concentrations in perfusate samples were measured using a solid phase kit (Diagnostic Products Corp., Los Angeles, CA). Progesterone antibody is bound covalently to the inner surface of polypropylene assay tubes. All samples and standards were assayed in duplicate. The intra- and interassay coefficients of variation were $7.5 \%$ and $6.6 \%$, respectively. Perfusate concentrations of $\mathrm{PGF}_{2 \alpha}$ were measured using a $\left[^{3} \mathrm{H}_{\mathrm{PGF}} \mathrm{Pa}_{2 \alpha}\right.$ radioimmunoassay kit (INCSTAR Corp., Stillwater, $\mathrm{MN})$. $\mathrm{PGF}_{2 \alpha}$ antibody crossreacts $1.2 \%$ with $\mathrm{PGF}_{2 \alpha}$ metabolite and less than $0.2 \%$ with other prostaglandin families. All samples and standards were assayed in duplicate.

\section{Statistical analyses}

Data are expressed as means \pm SEM. Data for $\mathrm{PGF}_{2 a}$ and progesterone concentrations were evaluated by analysis of variance, and $P<0.05$ was considered significant. Comparison of ovulatory efficiencies was performed using chi-square analysis and $P<0.05$ was considered significant. Dose-response studies were designed using a balanced block method; the order of the ovaries for each experiment was determined by a random number table.

\section{Results}

Effect of calcium/calmodulin-dependent protein kinase II substrate on ovulation and concentrations of progesterone and $P G F_{2 a}$ in the absence of $h C G$

Calcium/calmodulin-dependent protein kinase Il substrate induced ovulation in the in vitro perfused rabbit ovary in the absence of gonadotrophin. Ovulatory efficiency varied significantly from $0.0 \pm 0.0 \%$ for controls to $66.3 \pm 9.9 \%$ for ovaries perfused with calcium/calmodulin-dependent protein kinase II substrate $(P<0.01)$. When $\mathrm{KN} 62$ was added together with calcium/calmodulin-dependent protein kinase II substrate, it significantly reduced ovulatory efficiency to $6.3 \pm 6.3 \%$ $(P<0.01)$. However, progesterone and $\mathrm{PGF}_{2 \alpha}$ concentrations in perfusates from ovaries treated with either calcium/calmodulindependent protein kinase II substrate alone or calcium/ calmodulin-dependent protein kinase II substrate together with $\mathrm{KN} 62$ displayed no significant change from control ovaries.

Effects of calcium/calmodulin-dependent protein kinase II inhibitors on hCG-induced ovulation and concentrations of progesterone and $P G F_{2 a}$

Ovulatory efficiency was significantly reduced in ovaries treated with hCG and KN 62 at doses of $10^{-8}, 10^{-7}$ and $10^{-6} \mathrm{~mol} \mathrm{l}^{-1}$ (Table 1). Another calcium/calmodulindependent protein kinase II inhibitor, 281-302, also significantly inhibited hCG-induced ovulation from 79.6 $\pm 8.3 \%$ 
Table 1. Effect of KN 62, an inhibitor of calcium/calmodulin-dependent protein kinase II, on hCG-induced ovulation in the in vitro perfused rabbit ovary

\begin{tabular}{|c|c|c|c|c|c|}
\hline \multirow[b]{2}{*}{ Parameter } & \multicolumn{5}{|c|}{$\mathrm{KN} 62\left(\mathrm{~mol} \mathrm{l}^{-\mathrm{I}}\right)$} \\
\hline & 0 & $10^{-9}$ & $10^{-8}$ & $10^{-7}$ & $10^{-6}$ \\
\hline Number of perfused ovaries & 8 & 6 & 4 & 4 & 6 \\
\hline Number of ovaries ovulated & 8 & 6 & 4 & 4 & 4 \\
\hline Number of mature follicles & 51 & 38 & 22 & 29 & 43 \\
\hline Number of ovulations & 41 & 21 & 9 & 9 & 17 \\
\hline Ovulatory efficiency $(\%)^{a}$ & $80.9 \pm 5.5$ & $60.3 \pm 16.3$ & $40.0 \pm 7.1^{*}$ & $32.9 \pm 8.7^{* *}$ & $37.8 \pm 14.9^{*}$ \\
\hline
\end{tabular}

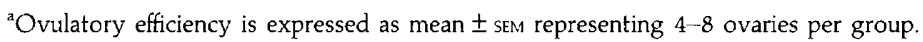

${ }^{*} P<0.05,{ }^{*} P<0.01$ compared with control $\left(0 \mathrm{~mol} \mathrm{I}^{-1}\right)$.

in ovaries perfused with hCG alone to $31.3 \pm 11.9 \%$ for $\mathrm{hCG}$ plus this inhibitor $\left(10^{-6} \mathrm{~mol} \mathrm{l}^{-1} ; P<0.01\right)$. Although hCG significantly increased progesterone concentration, neither $\mathrm{KN}$ 62 nor calcium/calmodulin-dependent protein kinase II inhibitor 281-302 affected hCG-induced progesterone production (control: $1.3 \pm 0.4 \mathrm{ng} \mathrm{ml}^{-1}$; hCG: $41.2 \pm 8.2 \mathrm{ng} \mathrm{ml}^{-1} ; \mathrm{hCG}+\mathrm{KN}$ $62\left[10^{-7} \mathrm{~mol} \mathrm{l} \mathrm{l}^{-1}\right]: 32.8 \pm 14.4 \mathrm{ng} \mathrm{ml}{ }^{-1}$; hCG + inhibitor 281-302: $32.7 \pm 13.2 \mathrm{ng} \mathrm{ml}^{-1}$ ). No significant change was observed in $\mathrm{PGF}_{2 \alpha}$ concentrations in the perfusate of any treated group when compared with the control group.

\section{Effect of calcium/calmodulin-dependent protein kinase II inhibitor} (KN 62) on PGF $2 a^{-i n d u c e d ~ o v u l a t i o n ~}$

$\mathrm{PGF}_{2 \alpha}$-induced ovulation was inhibited by $\mathrm{KN} 62$ at a dose of $10^{-6} \mathrm{~mol} \mathrm{l}^{-1}$. Ovulatory efficiency was significantly reduced in these experiments from $59.9 \pm 12.6 \%$ for ovaries perfused with $\mathrm{PGF}_{2 \alpha}$ alone to $21.5 \pm 8.9 \%$ for $\mathrm{PGF}_{2 \alpha}$ plus $\mathrm{KN}$ $62(P<0.05)$

Effect of L-NAME on ovulation induced by calcium/calmodulindependent protein kinase II substrate and hCG

Both calcium/calmodulin-dependent protein kinase II substrate-induced ovulation and hCG-induced ovulation were

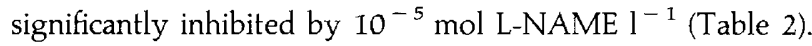

\section{Discussion}

In the study reported here, a rabbit ovarian in vitro perfusion model was used to investigate the role of the calcium/ calmodulin-dependent protein kinase II pathway in the process of foilicular rupture. A specific substrate for calcium/ calmodulin-dependent protein kinase II activates calcium/ calmodulin signal transduction by increasing calcium, which, in turn, results in binding of calcium to intracellular acceptors; calmodulin is a major acceptor (Colbran and Soderling, 1990; Hanson and Schulman, 1992). Calcium-bound calmodulin activates various enzymes including calcium/calmodulin-dependent protein kinase II (Colbran and Soderling, 1990; Hanson and Schulman, 1992). In the study reported here, calcium/ calmodulin-dependent protein kinase II substrate induced
Table 2. Effect of $N$-nitro-L-arginine methyl ester (L-NAME) on the ovulatory efficiency of calcium/calmodulin-dependent protein kinase II substrate-induced ovulation and hCG-induced ovulation in the in vitro perfused rabbit ovary

\begin{tabular}{lcc}
\hline & \multicolumn{2}{c}{$\operatorname{L-NAME}\left(10^{-5} \mathrm{~mol} \mathrm{l}^{-1}\right)$} \\
\cline { 2 - 3 } & - & + \\
\hline $\begin{array}{l}\text { CaMK-II substrate-induced ovulation } \\
\text { Ovulatory efficiency (\%) }\end{array}$ & $72.0 \pm 8.5$ & $32.0 \pm 13.2^{*}$ \\
$\begin{array}{l}\text { hCG-induced ovulation } \\
\text { Ovulatory efficiency }(\%)\end{array}$ & $79.8 \pm 10.4$ & $17.2 \pm 10.6^{* *}$ \\
\hline
\end{tabular}

Values are expressed as means \pm SEM.

${ }^{*} P<0.05, * * P<0.0$ I compared with control (L-NAME $(-)$ ).

ovulation in the extracorporeal perfused rabbit ovary in the absence of hCG. The mechanism(s) by which calcium/ calmodulin-dependent protein kinase II substrate brings about follicular rupture is not clear. It is possible that calcium/ calmodulin-dependent protein kinase II substrate, which is a peptide, acts on the outer surface of the cell membrane. If this substrate does affect calcium/calmodulin-dependent protein kinase II, the catalytic domain of the enzyme must be directed towards the outside of the cell or be present in the circulation. In this study, exogenous substrate does not appear to compete with the endogenous substrate(s) and inhibit steps in the calcium/calmodulin-dependent protein kinase II signal transduction pathway. It is feasible that ovulation may be mediated through plasma membrane receptors for calcium/calmodulindependent protein kinase II substrate.

Perfusate concentrations of $\mathrm{PGF}_{2 \alpha}$ and progesterone did not change following exposure to calcium/calmodulindependent protein kinase II substrate, suggesting that calcium/ calmodulin-dependent protein kinase II substrate-induced ovulation occurs independently of prostaglandin production, although it is possible that only threshold concentrations of prostaglandins are required for ovulation to occur. The mechanism(s) by which prostaglandins leads to follicular rupture requires further investigation.

Arachidonic acid metabolites, in particular $\mathrm{PGF}_{2 \alpha}$ and prostacyclin $\left(\mathrm{PGI}_{2}\right)$, are considered as intermediaries, acting 
between preovulatory gonadotrophin secretion and ovulation in rabbits as well as in other species (Wallach et al., 1992). Clearly, many factors are involved in the process of ovulation. Some of these factors may express themselves through an influence on ovarian prostaglandins. Indomethacin, a potent inhibitor of prostaglandin synthesis, inhibits ovulation in response to either gonadotrophin or $\mathrm{PGF}_{2 \alpha}$ and $\mathrm{PGI}_{2}$, but does not inhibit ovulation induced by the vasoactive agents, histamine and bradykinin, in the in vitro perfused rabbit ovary (Kitai et al., 1985; Yoshimura et al., 1988). The results of the experiments reported here do not refute the concept that prostaglandins mediate follicle wall disruption, but suggest that there are other mechanism(s) that are independent of, or act in conjunction with, prostaglandins.

Although prostaglandins may be involved in the release or activation of plasminogen activator within the follicle, blockade of prostaglandin synthesis does not inhibit tissue plasminogen activator secretion (Espey et al., 1985; Reich et al., 1985). The precise relationship between ovulation, tissue plasminogen activator and prostaglandins remains to be clarified. The results of the experiments reported here suggest that, although prostaglandins may be intermediaries in the process of ovulation, they need not be essential for calcium/ calmodulin-dependent protein kinase II substrate-induced follicle rupture.

The specific calcium/calmodulin-dependent protein kinase II inhibitor, $\mathrm{KN} \mathrm{62}$, was used in the perfusion model to study the role of the calcium/calmodulin-dependent protein kinase II signal pathway in gonadotrophin-induced ovulation. KN 62 , which is specific for calcium/calmodulin-dependent protein kinase II and crossreacts with neither cAMP-dependent protein kinase nor protein kinase $C$ pathways, binds to the calmodulin site of this enzyme (Tokumitsu et al, 1990). In this study, the inhibitors blocked hCG-induced ovulation. A larger dose of $\mathrm{KN} 62$ was required to achieve inhibition of calcium/calmodulin-dependent protein kinase II substrateinduced ovulation than to inhibit hCG-induced ovulation. This supports the concept that calcium/calmodulin-dependent protein kinase II may be involved in gonadotrophin-induced follicular rupture in rabbits. Therefore, it can be postulated that LH uses at least three signal transduction pathways to control separate cellular functions (i.e. CAMP-dependent protein kinase, the protein kinase $C$, and the calcium/calmodulindependent protein kinase II pathways). Little information is available on the effect of $\mathrm{LH}$ on calcium/calmodulindependent protein kinase II metabolism in rabbits. Other purported intermediaries of ovulation, including PGF $_{2 u^{\prime}}$ have been shown to activate the calcium/calmodulin-dependent protein kinase II pathway in several cell populations (Wegner et al., 1991). Consequently, calcium/calmodulin-dependent protein kinase II substrate-mediated follicular rupture may occur directly via hCG activation, or may result from the role of calcium/calmodulin-dependent protein kinase II as a second messenger for other intermediaries the release of which may be triggered by gonadotrophins.

In the present experiments, $\mathrm{KN} 62$ blocked $\mathrm{PGF}_{2 a}$-induced ovulation, implying that $\mathrm{PGF}_{2 \mu}$ has a direct effect on activation of the calcium/calmodulin-dependent protein kinase II signal transduction. Prostaglandin $\mathrm{F}_{2 u}$ has been shown to act on the proteolytic enzyme cascade, and this action may be either direct or indirect through calcium/calmodulin-dependent protein kinase II (Miyazaki et al., 1991b).

Inhibition of nitric oxide synthesis by L-NAME, an analogue of L-arginine, significantly reduces hCG-induced follicular rupture in rabbits (Hesla et al., 1993). This effect is demonstrated both in vivo and in vitro, when the ovary was isolated from systemic influences and directly exposed to the compound. Interleukin- $1 \beta$ induces nitric oxide synthase activity in the rat ovary (Ben-Shlomo et al., 1994) and induces ovulation in the rabbit ovary in the absence of gonadotrophin (Takehara et al., 1994). These findings suggest that nitric oxide production by the ovary is a component of the physiological processes that occur during the periovulatory period. There are two isoforms of nitric oxide synthase. The constitutive type (neural and endothelial nitric oxide synthase) is a calcium/calmodulindependent enzyme that releases nitric oxide for short periods in response to receptor stimulation (Moncada et al., 1991). The calcium/calmodulin dependence of neural nitric oxide synthase allows for its stimulation through first messengers or agents that increase intracellular calcium concentrations (Moncada et al., 1991). The resultant increase in calcium can then stimulate nitric oxide synthase as well as other calcium-dependent enzymes. The second form of nitric oxide synthase is inducible nitric oxide synthase. This form is calcium-independent and expressed after activation of cytokines (Hibbs et al., 1988). In this study, L-NAME significantly reduced calcium/calmodulindependent protein kinase II substrate-induced ovulation, suggesting that calcium/calmodulin-dependent protein kinase II brings about follicle rupture at least in part through stimulating nitric oxide synthesis.

In conclusion, this study demonstrates that the calcium/ calmodulin-dependent protein kinase II pathway has a role in gonadotrophin-induced follicular rupture in rabbits. Inhibition of $\mathrm{PGF}_{2 a}$-induced ovulation by calcium/calmodulin-dependent protein kinase II inhibitor indicates that $\mathrm{PGF}_{20}$-mediated follicular rupture may be achieved partially through activation of calcium/calmodulin signal transduction. Furthermore, the data supplement previous observations that suggest a role for nitric oxide in the overall process of follicular rupture.

The authors thank R. Ghodgaonkar for his help in statistical analysis, and B. Smith and D. Ward for technical assistance. This work was supported by: NIH HD-19430 (E. E. Wallach and A. M. Dharmarajan), Population Center Grant HD-06268 (A. M. Dharmarajan) and Rockefeller Foundation (A. M. Dharmarajan).

\section{References}

Adashi EY, Resnick CE and Jastorff A (1990) Blockade of granulosa cell differentiation by an antagonistic analog of adenosine $3^{\prime}, 5^{\prime}$-cyclic monophosphate (cAMP): central but non-exclusive intermediary role of cAMP in follicle-stimulating hormone action Molecular and Cellular Endocrinology $\mathbf{7 2}$ $1-11$

Ahrén K, Janson PO and Selstam G (1971) Perfusion of ovaries in vitro and in vivo Acta Endocrinologica Supplementum 158 285-309

Ben-Shlomo I, Kokia E, Jackson MJ, Adashi EY and Payne DW (1994) Interleukin-1 $\beta$ stimulates nitrite production in the rat ovary: evidence for heterologous cell-cell interaction and for insulin-mediated regulation of the inducible isoform of nitric oxide synthase Biology of Reproduction 51 $310-318$ 
Brännström M, Koos RD, LeMaire WJ and Janson PO (1987) Cyclic adenosine $3^{\prime}, 5^{\prime}$-monophosphate-induced ovulation in the perfused rat ovary and its mediation by prostaglandins Biology of Reproduction 37 1047-1053

Colbran RJ and Soderling TR (1990) Calcium/calmodulin-dependent protein kinase II Current Topics in Cellular Regulation 31 181-221

Davis JS, Weakland LL, West LA and Farese RV (1986) Luteinizing hormone stimulates the formation of inositol trisphosphate and cyclic AMP in rat granulosa cells Biochemical journal 238 597-604

Dharmarajan AM, Yoshimura Y, Sueoka K, Atlas SJ, Dubin NH, Ewing LL, Zirkin BR and Wallach EE (1988) Progesterone secretion by corpora lutea of the isolated perfused rabbit ovary during pseudopregnancy Biology of Reproduction 38 1137-1143

Endo K, Atlas SJ, Rone JD, Zanagnolo VL, Kuo TC, Dharmarajan AM and Wallach EE (1992) Epidermal growth factor inhibits follicular response to human chorionic gonadotropin: possible role of cell to cell communication in the response to gonadotropin Endocrinology 130 186-192

Espey L, Shimada H, Okamura H and Mori T (1985) Effect of various agents on ovarian plasminogen activator activity during ovulation in pregnant mare's serum gonadotropin-primed immature rats Biology of Reproduction 32 1087-1094

Hanson PI and Schulman H (1992) Neuronal $\mathrm{Ca}^{2+} / \mathrm{calmodulin}$-dependent protein kinases Annual Review of Biochemistry 61 559-601

Hesla JS, Preutthipan S, Chen SH, Wallach EE and Dharmarajan AM (1993) The role of nitric oxide on hCG-induced ovulation in the rabbit. In Proceedings of the 49th Annual Meeting of the American Fertility Society, Abstract P261

Hibbs JB, Jr, Taintor RR, Vavrin Z and Rachlin EM (1988) Nitric oxide: a cytotoxic activated macrophage effector molecule Biochemical and Biophysical Research Communications $15787-94$

Holmes PV, Hedin L and Janson PO (1986) The role of cyclic adenosine $3^{\prime}, 5^{\prime}$-monophosphate in the ovulatory process of the in vitro perfused rabbit ovary Endocrinology 118 2195-2202

Hosoi Y, Yoshimura Y, Atlas SJ, Adachi T and Wallach EE (1989) Effects of dibutyryl cyclic AMP on oocyte maturation and ovulation in the perfused rabbit ovary Journal of Reproduction and Fertility 85 405-411

Kaufman G, Dharmarajan AM, Takehara Y, Cropp CS and Wallach EE (1992) The role of protein kinase- $C$ in gonadotropin-induced ovulation in the in vitro perfused rabbit ovary Endocrinology 131 1804-1809

Kawai Y and Clark MR (1985) Phorbol ester regulation of rat granulosa cell prostaglandin and progesterone accumulation Endocrinology 116 2320-2326

Kitai H, Kobayashi Y, Santulli R, Wright KH and Wallach EE (1985) The relationship between prostaglandins and histamine in the ovulatory process as determined with the in vitro perfused rabbit ovary Fertility and Sterility $\mathbf{4 3}$ 646-651

Kobayashi Y, Wright KH, Santulli R and Wallach EE (1981) Ovulation and ovum maturation in the rabbit ovary perfused in vitro Biology of Reproduction $\mathbf{2 4}$ $483-490$

Kuo T-C, Endo K, Dharmarajan AM, Miyazaki T, Atlas SJ and Wallach EE (1991) Direct effect of angiotensin II on in vitro perfused rabbit ovary Journal of Reproduction and Fertility 92 469-474
Lambertsen CJ Jr, Greenbaum DF, Wright KH and Wallach EE (1976) In vitro studies of ovulation in the perfused rabbit ovary Fertility and Sterility $\mathbf{2 7}$ 178-187

LeMaire WJ and Marsh JM (1975) Interrelationships between prostaglandins, cyclic AMP and steroids in ovulation Journal of Reproduction and Fertility Supplernent 22 53-74

Leung PCK and Wang J (1989) The role of inositol lipid metabolism in the ovary Biology of Reproduction 40 703-708

Miyazaki T, Sueoka K, Dharmarajan AM, Atlas SJ, Bulkley GB and Wallach EE (1991a) Effect of inhibition of oxygen free radical on ovulation and progesterone production by the in vitro perfused rabbit ovary Journal of Reproduction and Fertility 91 207-212

Miyazaki T, Dharmarajan AM, Atlas SJ, Katz E and Wallach EE (1991b) Do prostaglandins lead to ovulation in the rabbit by stimulating proteolytic enzyme activity? Fertility and Sterility 55 1183-1188

Moncada S, Palmer RMJ and Higgs EA (1991) Nitric oxide: physiology, pathophysiology and pharmacology Pharmacological Reviews 43 109-142

Rasmussen H and Rasmussen JE (1990) Calcium as intracellular messenger: from simplicity to complexity Current Topics in Cellular Regulation 31 1-109

Reich R, Miskin R and Tsafriri A (1985) Follicular plasminogen activator: involvement in ovulation Endocrinology 116 516-521

Strickland S and Beers WH (1976) Studies on the role of plasminogen activator in ovulation Journal of Biological Chemistry 251 5694-5702

Takehara Y, Dharmarajan AM, Kaufman G and Wallach EE (1994) Effect of interleukin- $1 \beta$ on ovulation in the in vitro perfused rabbit ovary Endocrinology 134 1788-1793

Tokumitsu H, Chijiwa T, Hagiwara M, Mizutani A, Terasawa M and Hidaka $H$ (1990) KN-62, 1-[N,O-Bis(5-isoquinolinesulfonyl)- $N$-methyl-L-tyrosyl]-4phenylpiperazine, a specific inhibitor of $\mathrm{Ca}^{2+} /$ calmodulin-dependent protein kinase II Journal of Biological Chemistry 265 4315-4320

Wallach EE and Dharmarajan AM (1992) Prostaglandins and ovulation. In Local Regulation of Ovarian Function pp 171-181 Eds N-O Sjöberg, L Hamberger, PO Janson, Ch Owman and HJT Coelingh Bennink. The Parthenon Publishing Group Ltd, Lancs UK and New Jersey USA

Wegner JA, Martinez-Zaguilan R, Gillies RJ and Hoyer PB (1991) Prostaglandin $\mathrm{F}_{2 \mathrm{u}}$-induced calcium transient in ovine large luteal cells: II. Modulation of the transient and resting cytosolic free calcium alters progesterone secretion Endocrinology 128 929-936

Yoshimura Y, Santulli R, Atlas SJ, Fujii S and Wallach EE (1987) The effects of proteolytic enzymes on in vitro ovulation in the rabbit American Journal of Obstetrics and Gynecology 157 468-475

Yoshimura Y, Espey L, Hosoi Y, Adachi T, Atlas SJ, Ghodgaonkar RB, Dubin NH and Wallach EE (1988) The effects of bradykinin on ovulation and prostaglandin production by the perfused rabbit ovary Endocrinology 122 $2540-2546$

Yoshimura Y, Hosoi Y, Atlas SJ, Ghodgaonkar R, Dubin NH, Dharmarajan AM and Wallach EE (1994) Inhibition of gonadotrophin-induced ovulation in rabbits by perfusion with dibutyryl cAMP via reduction of ovarian prostaglandin production Journal of Reproduction and Fertility 101 207-212 